\title{
"People for a Nation" (PFN) Model: How Can We Manage the Causes of the Discontent of Romanians Who Decide to Emigrate
}

\author{
Ileana Daniela DRAGNE 1 \\ Constantin Iulian TÃNASCU 2 \\ Robert Andrei COSTACHE 3 \\ Dan Cezar OSICEANU 4 \\ Alina Nicoleta BIIRSAN 5
}

DOI: $10.24818 / \mathrm{mer} / 2021.12-03$

\begin{abstract}
We live in a world that is constantly changing and that requires from the individuals in the society a flexibility and a very high degree of adaptation. Every change, whether economic, political, social or otherwise, has a major impact on the lives of all people and often not a positive impact. Because many individuals are inflexible and do not embrace change with enthusiasm, courage, and looking to the future, this makes them adopt a position of rejection of the country, of the systems that make up that country, of reluctance toward politics, and a general state of dissatisfaction. All this, combined, increases the desire of individuals to leave their country of origin to take refuge in a country where they have greater security and where they can embrace or are helped by the state to embrace change much faster and more effectively, so that does not suffer. The tendency of people to go to an area that offers them greater opportunities is not something new for the study of the migration phenomenon, on the contrary, it is something that has been studied and understood. What is interesting is that we can develop a model for determining a nation's desire to migrate based on the inconveniences or shortcomings it encounters in everyday life. The research we propose aims to identify the proportions that make up the population's desire to emigrate, by areas and systems and which, put together, can develop a deterministic model that we have called PFN (People for a Nation). This model allowed us not only to determine the level of desire to migrate to another country, but also gave us the opportunity to characterize a country according to those elements that bother individuals more or less.
\end{abstract}

KEYWORDS: PFN model, migration, desire to migrate, migration factors

JEL CLASSIFICATION: $F 22 ; J 11 ; J 24 ; R 23$

\section{INTRODUCTION}

A complex social phenomenon, existing since ancient times, migration continues to be one of the most important social problems that have often changed the fate of mankind (Bortnyk et al., 2018; De Paula \& de Mello, 2021; Duy, 2014). Ever since the movement of the population within the borders of a state could be measured, people have tried to identify the motivations that determined the mobility of human resources. In this sense, although there are many

\footnotetext{
${ }^{1}$ Bucharest University of Economic Studies, email: ddba0406@yahoo.com

${ }^{2}$ Bucharest University of Economic Studies, email: Tc_iulian@yahoo.com

${ }^{3}$ Bucharest University of Economic Studies, email: robertandreicostache@ gmail.com

${ }^{4}$ Valahia University of Târgoviște, email: cezarosiceanu@yahoo.com

${ }^{5}$ Bucharest University of Economic Studies, email: alina@ab-traduceri.ro
} 
scientific papers based on in-depth analyzes (Connell, 2021; Defoort, 2008; Samofalova, 2019; Stoica, 2017;), the leaders of states in which the migration phenomenon manifests itself intensely ignore the conclusions of studies in this field. and / or have other priorities, for various reasons. Consequently, those leaders do nothing to prevent, diminish or even eliminate the profoundly negative results of migration. An extremely relevant case in this regard is, for example, the migration of doctors from Romania (Botezat \& Moraru, 2020). For example, only in 2020, the first year of the SARS-CoV-2 pandemic, every 4 hours Romania was left by a doctor (Neagu, 2021), although salaries in this field have become extremely motivating. Also, by 2019, a third of Romanian doctors - for which the state has spent more than 10 billion. Euro - they emigrated, this share representing an absolute world record (Peticilă, 2019). We are inclined to believe that security and the chance to develop much more harmoniously than in Eastern countries have made Western countries much more attractive to migrants. Can we conclude, however, that migration is influenced only by the security and development capacity of other countries? We tend to answer "yes" but, returning to the situational example of Romania, it is still necessary to investigate, especially if we refer to the period of the first two decades of the 21 st century. Especially since Romania has been out of the former Soviet bloc for more than 30 years, migration problems have sharply intensified. In search of the western "paradise" and the dream of a much better life, Romanians began, since 1990, to leave the borders of their country en masse. And this began to become more and more obvious, with villages becoming more and more depopulated. This is confirmed by the demographic pyramids of 2000 and 2020, respectively (the last complete year from a statistical point of view).

The main purpose of this article is to make an analysis of those elements that displease Romanians, that make them want to emigrate and, based on these grievances and their quantification, to make the People For Nation (PFN) model. This model can determine those factors that act directly proportionally on the desire of Romanians to emigrate. In other words, depending on their answers, we can identify the first 4 systems that do not work well in Romanian society and we can, based on them, turn our attention to highlight correction methods and strategies that gradually reduce the number of those who want to leave the country. At the same time, this model can be spread over each state, being made so as to be flexible, the main limitations being access to the population of that state.

The article is made up of three parts. The first part is made up of the current state of knowledge in the field of migration, by pointing out the essential information that researchers who have studied this phenomenon have previously discovered. The second part includes an analysis based on a questionnaire applied to a number of 204 people, who live both in Romania and in other countries in Europe and the world to identify the elements we need to complete the third part. The third part includes the development of the People For Nation (PFN) model, which is based on the information we obtained from the analysis based on the questionnaire.

\section{LITERATURE REVIEW}

The issue of migration is the center of intense concerns since the 1990s. This, especially in the context in which Romania lost, between 1990-2020, millions of inhabitants. In this context, the latest statistics show that, out of a total of 9.7 million Romanians abroad, 5.6 million live in the diaspora and the rest in historical communities (Intotero, 2019). The reasons that generated the emigration of such a large number of Romanian's were corruption, the poor quality of the political class and poverty (Intotero, 2019). 
Basically, the specialists consider that about one fifth of the Romanians are willing to go to work abroad (Ion, 2021). It is hallucinatory that this trend is becoming more and more pronounced, although politicians claim that fewer and fewer Romanians are leaving their homeland.

As a whole, the situation of Romanian migration can be a paradox for many fellow citizens. For researchers, however, Romania is a country where people, and especially young people, are very dissatisfied with more and more facts. And the growing dissatisfaction of the population has led to a reorientation of the future of millions of Romanians to other countries, regions and / or areas (Booth \& Spade, 2003; King \& Skeldon, 2010; Sandu et al., 2017; Sheridan, 2020).

The migration of Romanians is not, however, a recent phenomenon. Thus, the negative phenomenon of migration began during World War I and continued to manifest itself more and more strongly. And this phenomenon has not been isolated (Matichescu et al. 2015). In a short time, Romania became the vice-champion of intra-European migration, being the only country that, although not in a state of war, registered such a significant migration phenomenon (Lavenex, 2005; Serban \& Toth, 2007).

We can say with certainty that the world has changed since the First World War and until now and we can say with certainty that Romania has changed. However, what can be the causes that generate migration? Are there other countries that are in the situation of Romania? The last question forces us to look at the statistical data, which we did and we were able to observe the following:

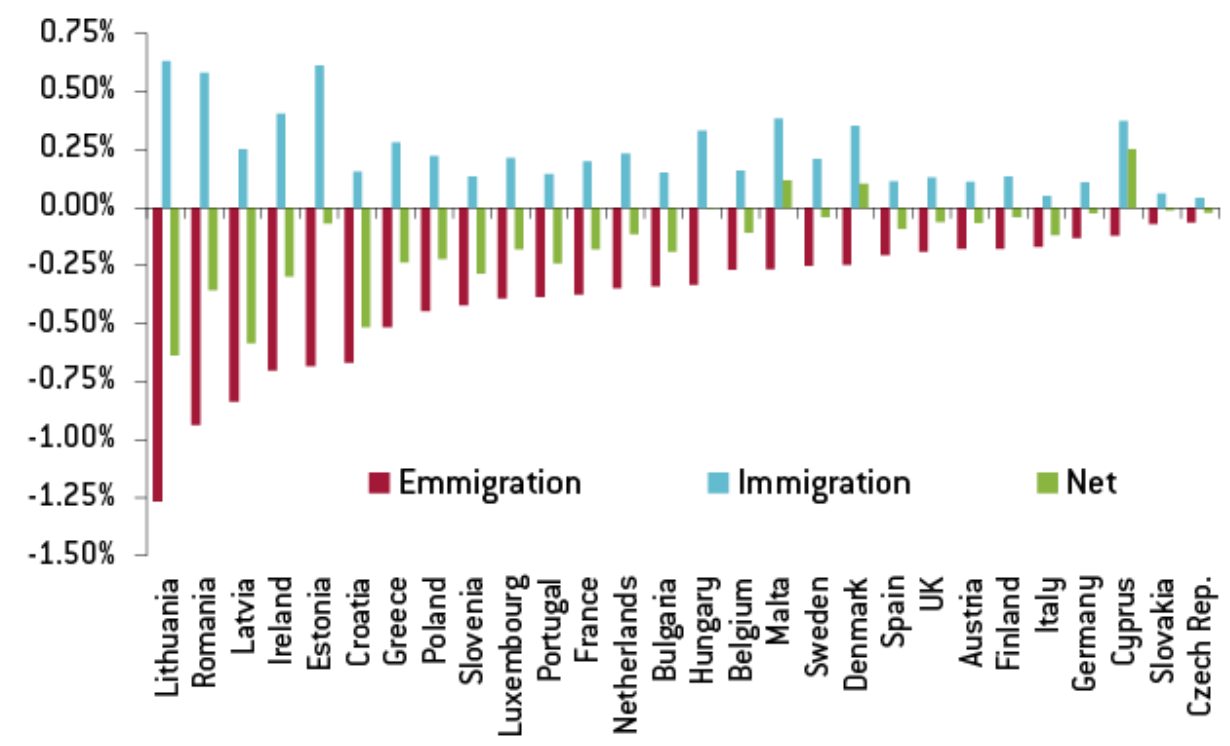

Figure 1. Migration in Europe

Source: Based on Naydenov (2018) analysis

We find that Lithuania is in first place in terms of migration and is followed by Romania, but if we analyze the level of the population and the number of migrants we will notice that Romania takes its place. However, we notice that it is a problem in Eastern Europe because a lot of people want to emigrate from here. The main reason is the level of development and dissatisfaction of the population, and the situation must be understood by looking back. The countries of Eastern Europe are part of the former USSR, which meant a sudden change of mentality, culture, vision (Penninx, 2008). 
Western countries, highly sought after by migrants from the East, are countries that have not shown any major cultural changes and have not had periods that will change their development trajectory much (Ilahi et al., 2016). We tend to believe that security and the chance to develop much more harmoniously than Eastern countries have made Western countries much more attractive to migrants. Can we thus conclude that migration is influenced only by security and development capacity? We tend to approve, but then we return to the example and situation of Romania and we have to investigate. This additional investigation is requested by Romania from 2000-2020. Romania left the former USSR bloc a long time ago, and from the communist period immediately after 1989, but there are still big problems in terms of migration. Although this can be seen with the naked eye on every alley of almost deserted villages or on the streets of cities that are frequented by fewer and fewer people, the situation is confirmed by the population pyramids of 2000 and 2020 (last full year). These can be seen below:

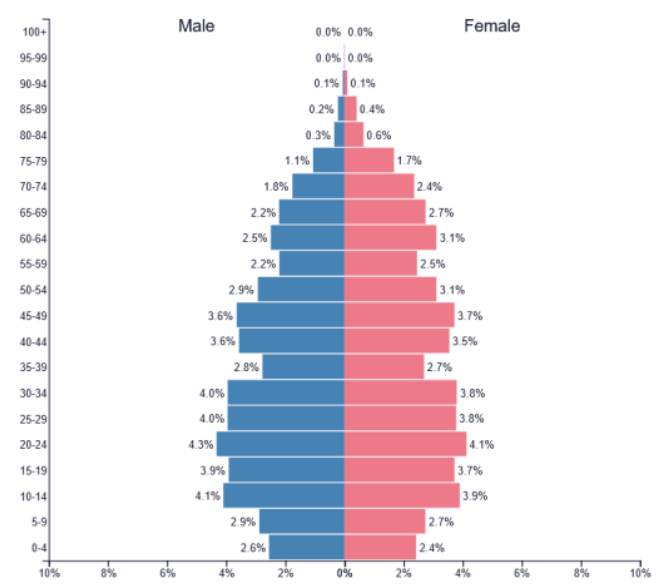

Figure 2. Population pyramid from 2000

Source: Based on (Population Pyramid, 2000)

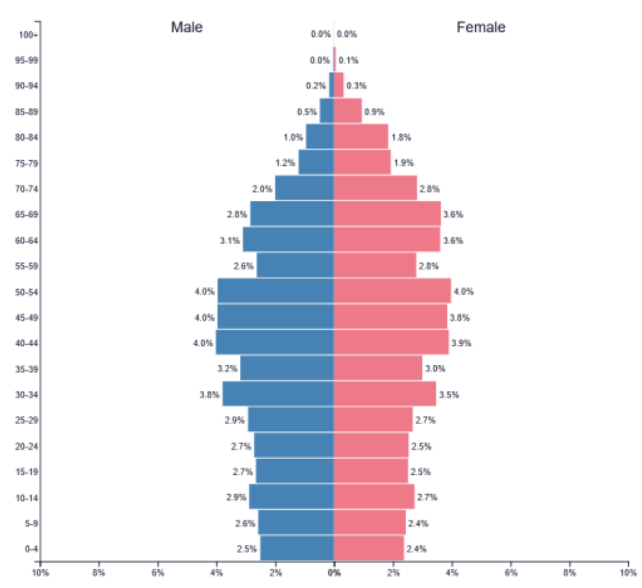

Figure 3. Population pyramid from 2020

Source: Based on (Population Pyramid, 2020)

It is found that the number of young people in 2000 was much higher. If the majority were those aged 10-34 years, the year 2020 surprises an aging population, with people aged 40-54 years, and fewer and fewer young people. We also find that in 2020 there are still 18.2 million people (National Institute of Statistics, 2020), compared to 2000, when there were 22.4 million people (National Institute of Statistics, 2020). All these fluctuations are no longer related for sure. All these fluctuations and the accelerated population decline have nothing to do with the fact that people no longer give birth to children or that many people die.

The main reasons why the pyramids of the Romanian population expose us to a difficult situation represented by a small number of young people and a large number of elderly people, can also be explained by migration. If during the years 1990-2000 Romania registered a clear pattern of migrants - the ethnics left the country, there were significant changes in the pattern of Romanian migrations starting with the year 2000 (Alexe, 2019). After the fall of the Communist Regime and after some of their relatives and friends had emigrated since 1990, those who remained in the country had a greater openness and diversified opportunities to go to the West. The willingness to leave the country reached its peak with Romania's accession to the European Union and continues without a break since then, generating problems for Romania and an uncertain future. 
The countries that compatriots have chosen to be "destination countries" are those in Western Europe and those in the North. The distribution of Romanians, as well as the countries in which they migrated, can be observed in figure no. 4 :

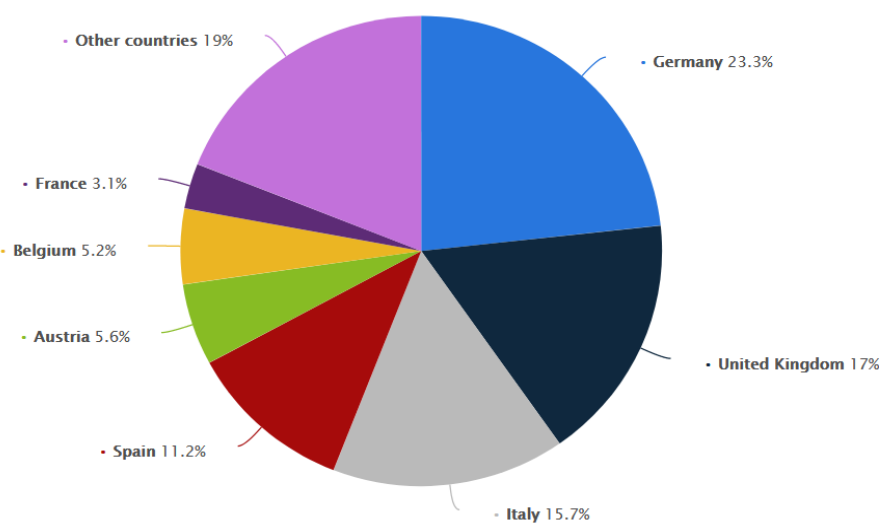

Figure 4. Destination countries for romanians

Sursa: Based on an analysis made by Sava (2021)

We notice that Romanians have left for those countries where the pillars of society (education, politics, social policy and economy) are very well developed, respected, and the people who work in those fields and who have a great impact on all citizens, allocate a level of substantial importance.

Also, a very important thing to point out in the situation in which Romania was at that time is the fact that a percentage of over $50 \%$ of those who left the country, went to Germany, the United Kingdom of Great Britain and Ireland. North, Italy and Spain. If Germany is not a surprise (almost one million Romanian citizens, who were of Hungarian, Saxon or Szekler ethnicity, left the country between 1990-2000), in the case of other countries, we can understand that the two main reasons that stood at the base of the departure are represented by dissatisfactions related to the good functioning of the pillars, in general, and an impossibility to benefit from a good salary, related to the level of work submitted, in particular.

All these causes of population decline are real causes, but they are not the most important. The most important cause of the accelerated population decline is the permanent migration of Romanians to other countries.

On the other hand, Romania is not only a country of people leaving, it is also an attractive country for citizens from other countries, especially from the east, countries that are underdeveloped or developing. According to a study (EURES, 2019), in 2018, 12,000 new living premises were registered for the last 12 months, with $17.1 \%$ more citizens compared to 2018. The structure of this increase includes $38.2 \%$ migrants who want to $26.6 \%$ family members, $25.2 \%$ people who came to study in Romania and $10 \%$ other types of migrants. From the point of view of migrants who came to Romania, we can meet citizens from the Republic of Moldova, Vietnam and Turkey, but also people from Iraq, Syria and Afghanistan. A large part of them came to Romania in search of a solution to cross the border and go to the west, and their stay, even if for a period longer than 12 months is, in reality, uncertain. 
Returning to the situation of the Romanians, they decided to return to Romania at the beginning of the pandemic. According to a study (The Economist, 2021), the pandemic caused 1.3 million people to return to the country. The reason why they decided to leave the destination countries and return to Romania is because they want to be with their family in these difficult times. There is absolutely no guarantee that at the end of the pandemic they will remain in Romania.

Thus, in order to see what are the reasons that make them leave, during the present research, we will see which are those pillars of the Romanian society that do not work properly. These reasons will be observed by creating the People for Nation (PFN) model, a model made with the help of quantitative research.

The study conducted by us is based on quantitative research, which was conducted using a questionnaire. It was distributed online, both to groups of Romanian citizens living in Romania and to groups of Romanians who have left the country but are aware of the situation in Romania. The analysis submitted for attention was carried out between March 2021 and May 2021 and has a sample of 204 people. Of these, 58 are men and 146 women, with an age range between 18-63 years, with an average age of 30.1 years.

The questionnaire was made with the help of the tool found on the Isondaje.ro website and contains questions that are easy to understand by the sample selected by me. The latter can answer very easily, because the questions we have brought to their attention are questions with suggested answers. The reason for choosing this type of question is to avoid situations in which they can answer with something else that is not necessarily related to the subject of the question.

\section{METHODOLOGY, ANALYZE AND RESULTS}

The analysis we performed is based on a quantitative research developed with the help of a survey. This analysis was performed on a sample of 204 people, 58 men and 146 women. The ages of the respondents are between 18-63, and the questionnaire has an average age of 30.1 years. To develop our analysis and to build the model, it is important to see how the sample answered the proposed questions. The first big question had several small questions. The sample was asked to choose a grade between 1 (little) and 8 (very much) depending on how much a statement influences their desire to migrate. Their answers can be seen below:

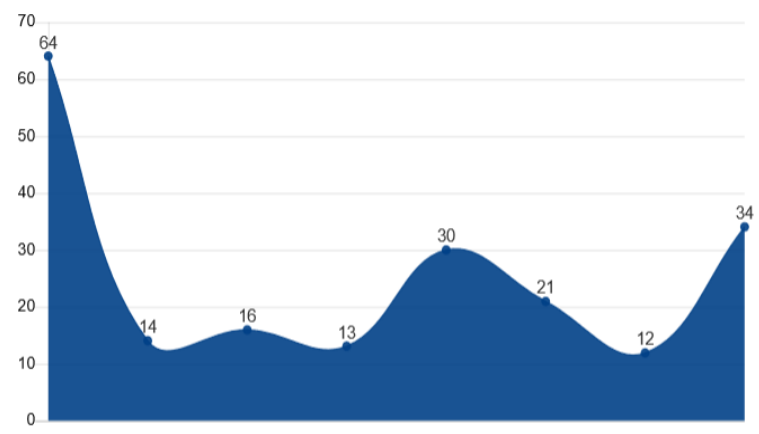

Figure 5. How much does the experience as a student in primary school and high school influences the desire to migrate.

Source: Made by the authors based on the questionnaire available at www.isondaje.ro/sondaj/837651639/

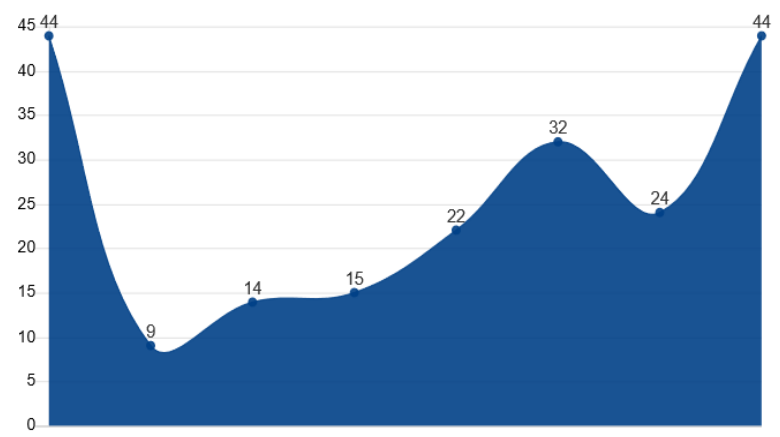

Figure 6. How much does the experience as a student in university (bachelor's, master or PHD) influences the desire to migrate

Source: Made by the authors based on the questionnaire available at www.isondaje.ro/sondaj/837651639/ 
Figure number 5 captures the influence that the experience of primary and high school has on the motivation of those surveyed to migrate. We notice that the most important institutions for basic skills are also the most neglected by Romanians. We can see that only 34 Romanians are upset because of the situation of primary and secondary education. Most of them, respectively 64 individuals, state that the experience in these two educational institutions does not stimulate the desire to leave the country. We cannot observe the same thing in the case of figure number 6 . Here we notice that people are equally upset, but also satisfied, with the experience they had with the universities. We notice that the poles (a littlea lot) record the same number of people surveyed, which makes us unable to express a point of view.

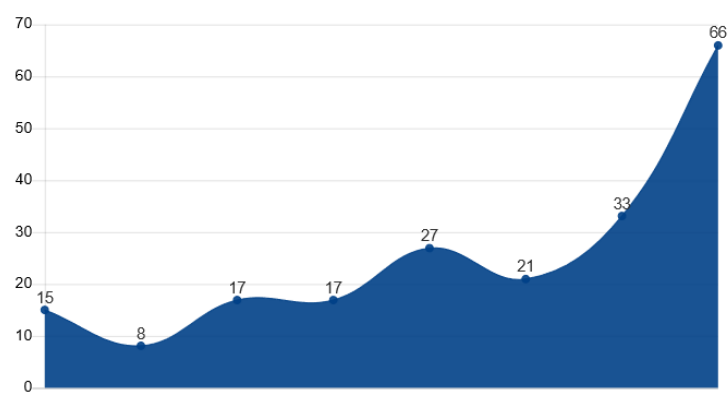

Figure 7. How much does the experience with education opportunities influences the desire to migrate?

Source: Made by the authors based on the questionnaire available at www.isondaje.ro/sondaj/837651639/

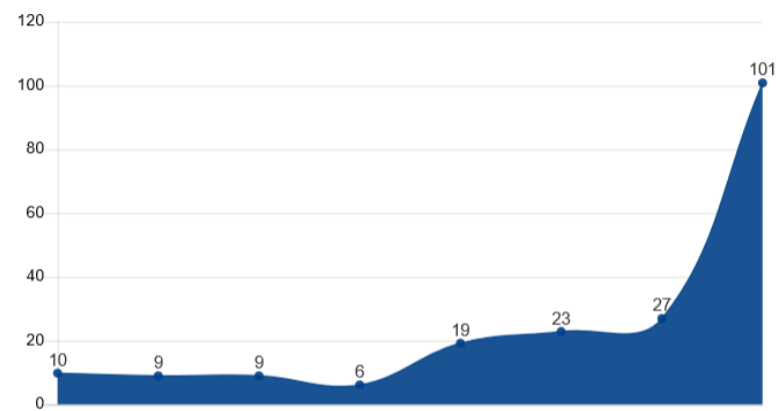

Figure 8. How much does the desire for migration is influenced by the experience with endowments of educational institutions?

Source: Made by the authors based on the questionnaire available at www.isondaje.ro/sondaj/837651639/

Figure number 7 identifies the fact that Romanians are very sensitive to educational opportunities. A lack of them or low-quality educational opportunities makes Romanians want to migrate. We have a clear trend on this question, which implies a first reason for migration. In figure number 8 we wanted to see how much the endowments that the educational institutions have influence the desire to migrate the sample. And this time, we can identify a clear trend and a second reason why people want to migrate.

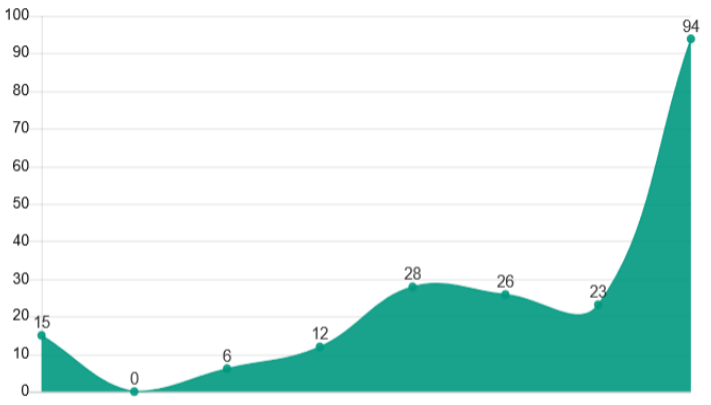

Figure 9. How much does the degree of culture influences the desire to migrate?

Source: Made by the authors based on the questionnaire available at www.isondaje.ro/sondaj/837651639/

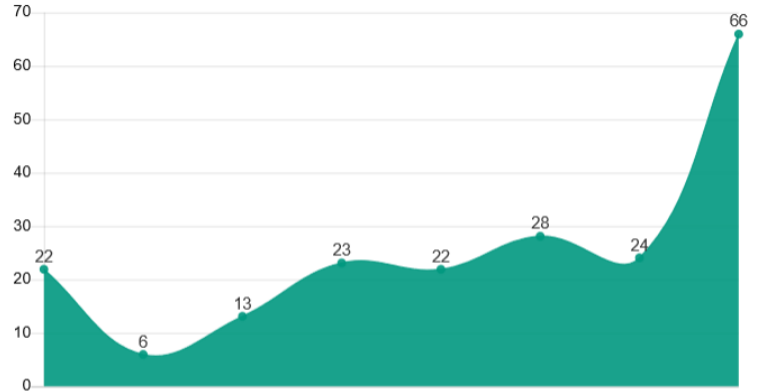

Figure 10. How much does the access to culture influences the desire to migrate?

Source: Made by the authors based on the questionnaire available at www.isondaje.ro/sondaj/837651639/ 
Figure number 9 shifts the attention of the questionnaire from the educational field to the cultural one. We can see that the degree of culture of compatriots is a reason for migration. The more uneducated individuals are, the more the others who are around the average or above average in terms of culture are more disturbed and more determined to leave. And this time we get a trend that indicates another reason for migrants of Romanians. Also in the cultural field, figure number 10 indicates the level of influence of the desire to migrate in case of access to culture. Restricting access, a lack of access or a lack of culture strongly influences the desire of the population. However, compared to Figure 9, there are more people who are careless when it comes to access to culture, 22 people (in Figure 10) compared to 15 (in Figure 9).

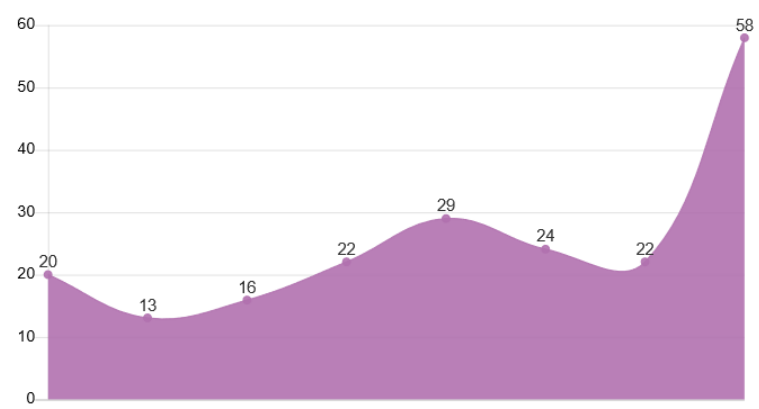

Figure 11. How much it influences the desire to migrate, the touristic capital?

Source: Made by the authors based on the questionnaire available at www.isondaje.ro/sondaj/837651639/

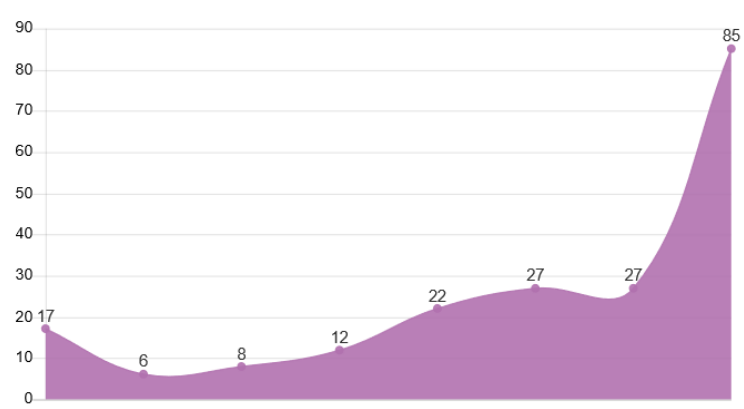

Figure 12. How does the quality of touristic services influences the desire to migrate.

Source: Made by the authors based on the questionnaire available at www.isondaje.ro/sondaj/837651639/

From culture we can take the discussion in the field of tourism, because the two have more in common. In figure number 11 we focused on highlighting the influence of the desire to migrate depending on the tourist capital. Many people are not satisfied with domestic tourism and decide to leave without or not seeing the tourist capital. We can see from here another reason for the Romanians to migrate. They would like to leave Romania only because the total tourist capital is unsatisfactory. Moreover, in figure number 12 we find out that Romanians are much more motivated to leave the country due to the poor quality of tourist services. We find out, in this case, that 85 people want to leave as a result of poor quality tourist services.

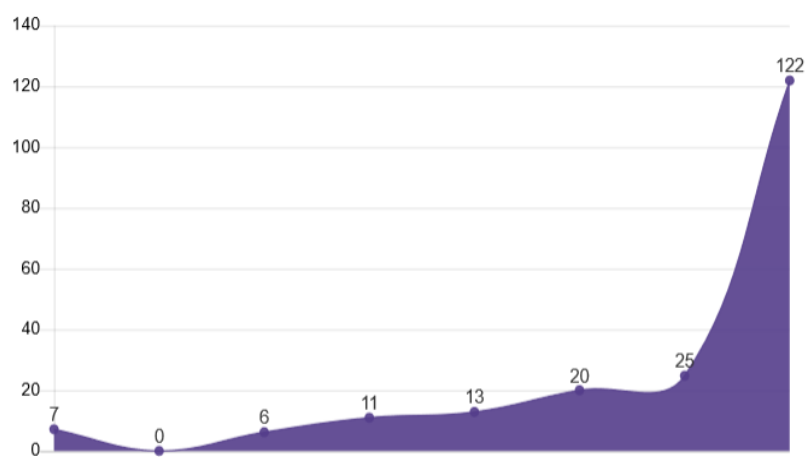

Figure 13. How does the health services influences the desire to migrate?

Source: Made by the authors based on the questionnaire available at www.isondaje.ro/sondaj/837651639/

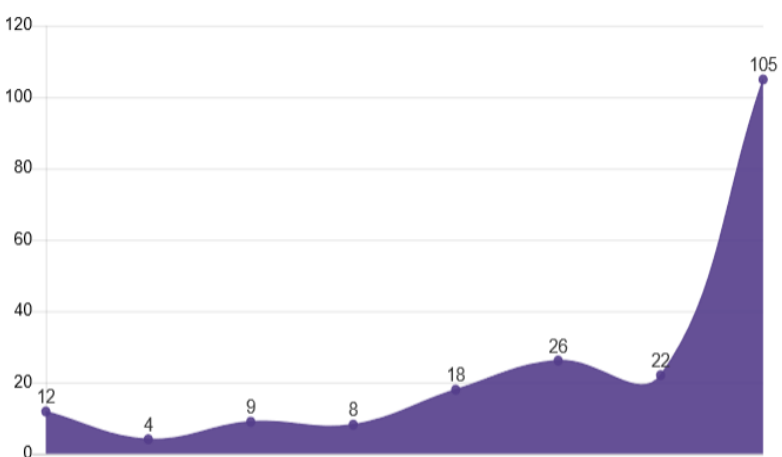

Figure 14. How does the number of health institutions influences the desire to migrate?

Source: Made by the authors based on the questionnaire available at www.isondaje.ro/sondaj/837651639/ 
Figure number 13 shows the impact that health services have on the desire of Romanians to migrate. It can be seen that Romanians, like any other nation, are very sensitive to health services, which makes them want to migrate from Romania. Figure number 14 shows us that a very high impact on the desire of Romanians to migrate is generated by the number of health units which, instead of being higher and higher, decreases every year.

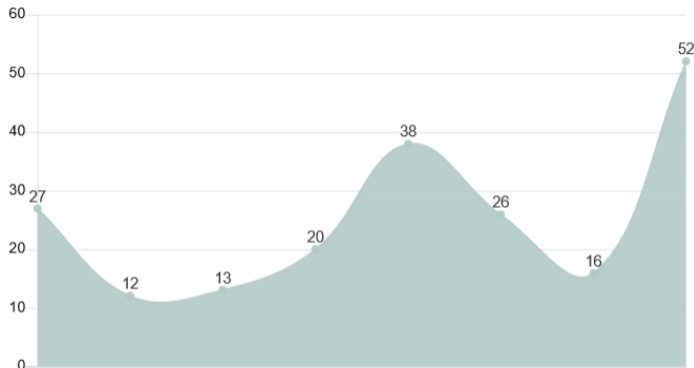

Figure 15. How does the lack of sport infrastructure influences the desire to migrate?

Source: Made by the authors based on the questionnaire available at www.isondaje.ro/sondaj/837651639/

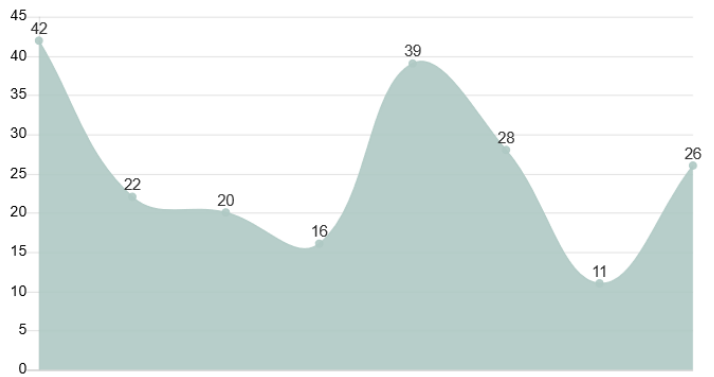

Figure 16. How does the lack of sport models influences the desire to migrate?

Source: Made by the authors based on the questionnaire available at www.isondaje.ro/sondaj/837651639/

In figure number 15 we notice an interesting thing. For Romanians, the lack of sports infrastructure is a reason for migration, but not as obvious as in the case of the other variants. We also notice that there are 38 people who are undecided about the impact of sports infrastructure on the desire to migrate. Moreover, according to figure number 16 we can see that the lack of models in sports does not make Romanians migrate, it even leaves them indifferent.

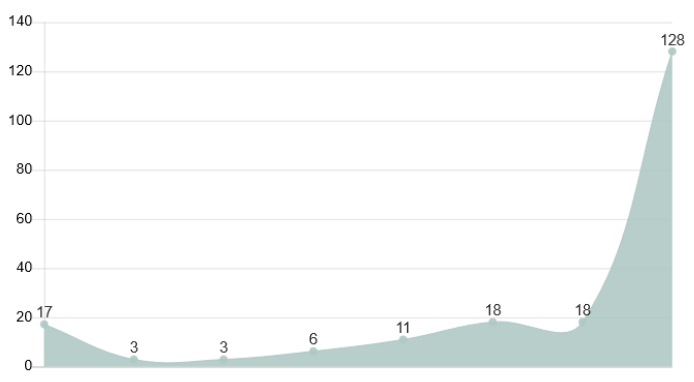

Figure 17. How does the lack of ethics for the politicians influences the desire to migrate?

Source: Made by the authors based on the questionnaire available at www.isondaje.ro/sondaj/837651639/

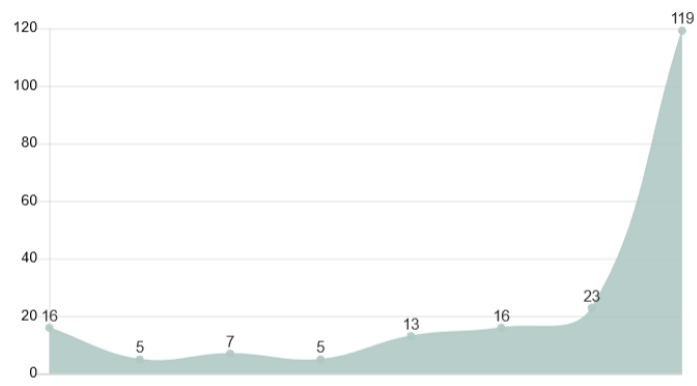

Figure 18. How does the lack of leadership influences the desire to migrate?

Source: Made by the authors based on the questionnaire available at www.isondaje.ro/sondaj/837651639/

Figure number 17 shows how much the lack of ethics of politicians influences the desire of Romanians to migrate. Without question, there is a trend and certainty regarding this aspect. The lack of ethics of politicians is a reason for migration. Simultaneously with this aspect, we can also point out the result from figure number 18, which confirms the fact that the lack of leadership in politics makes Romanians migrate. 


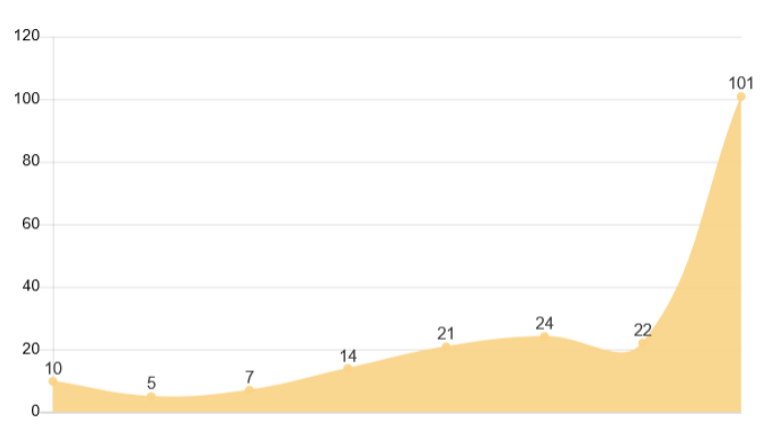

Figure 19. How does the opportunities in career influences the desire to migrate?

Source: Made by the authors based on the questionnaire available at www.isondaje.ro/sondaj/837651639/

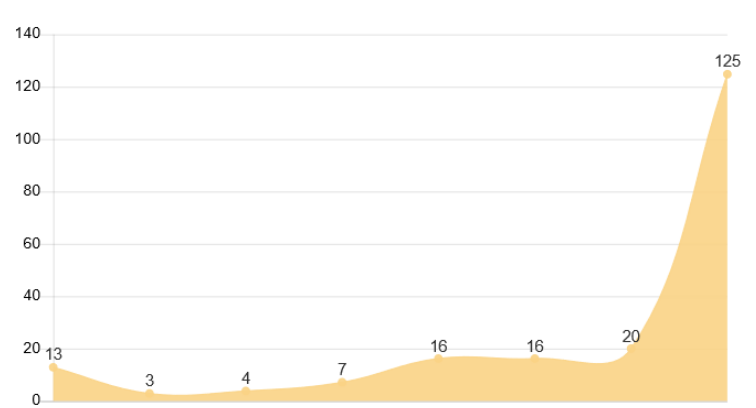

Figure 20. How does the birocracy influences the desire to migrate?

Source: Made by the authors based on the questionnaire available at www.isondaje.ro/sondaj/837651639/

In terms of career and career opportunities, we can see that Romanians are very sensitive to this topic. This can be explained in terms of security. Career opportunities can provide more security in people's lives, which is why the desire to migrate is high if the opportunities are few or non-existent. At the same time, if we look at figure 19 we can see another obvious reason for migration. Whether we are talking about the citizen as an employee or as a simple individual in society, he is hit by bureaucracy. This is one of the reasons why they would migrate to a country that is much more digitized in terms of documents and files that public or private institutions work with.

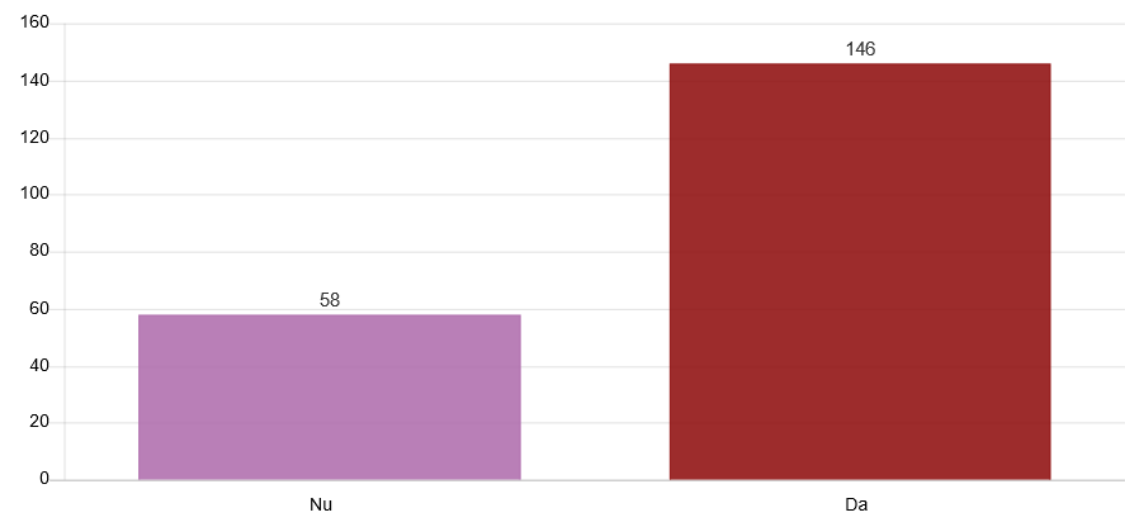

Figure 21. Have you ever thought of leaving Romania?

Source: Made by the authors based on the questionnaire available at www.isondaje.ro/sondaj/837651639/

In figure number 21 we can see that the situation is not good for Romania. The people who were interviewed were chosen at random, but they all live in Romania. We find, however, that out of the total sample that answered the questions, 146 want to leave the country and migrate to a country that fits their needs and aspirations. Moreover, this question makes a connection with the other previous questions addressed to the sample. If the answers were in the range [1,4] then we talk about people satisfied with the situation in Romania and the systems and domains in our country. However, the results showed that, apart from two questions, many are in the range [5,8]. This explains the fact that they are totally dissatisfied with certain aspects, systems or areas, which can be easily seen in figure number 21 . 
Next, as a confirmation of all the answers obtained previously, we will observe which are the main areas that have an impact on the desire of Romanians to migrate. Based on the following answers, which represent a conclusion of all the above questions, we will make the deterministic model of migration and explain how it should be interpreted so that it is understood and useful in decision making. To make the model, based on the questions, we will make the following assumptions: The field with the greatest impact on the migration desire of Romanian citizens is politics; Health, Education and the Social field are very sensitive topics for Romanians, areas that have a great impact on their desire to migrate; Sport has the least impact. The existence or non-existence of sports models, sports infrastructure or sports education is a topic that interests Romanians very little.

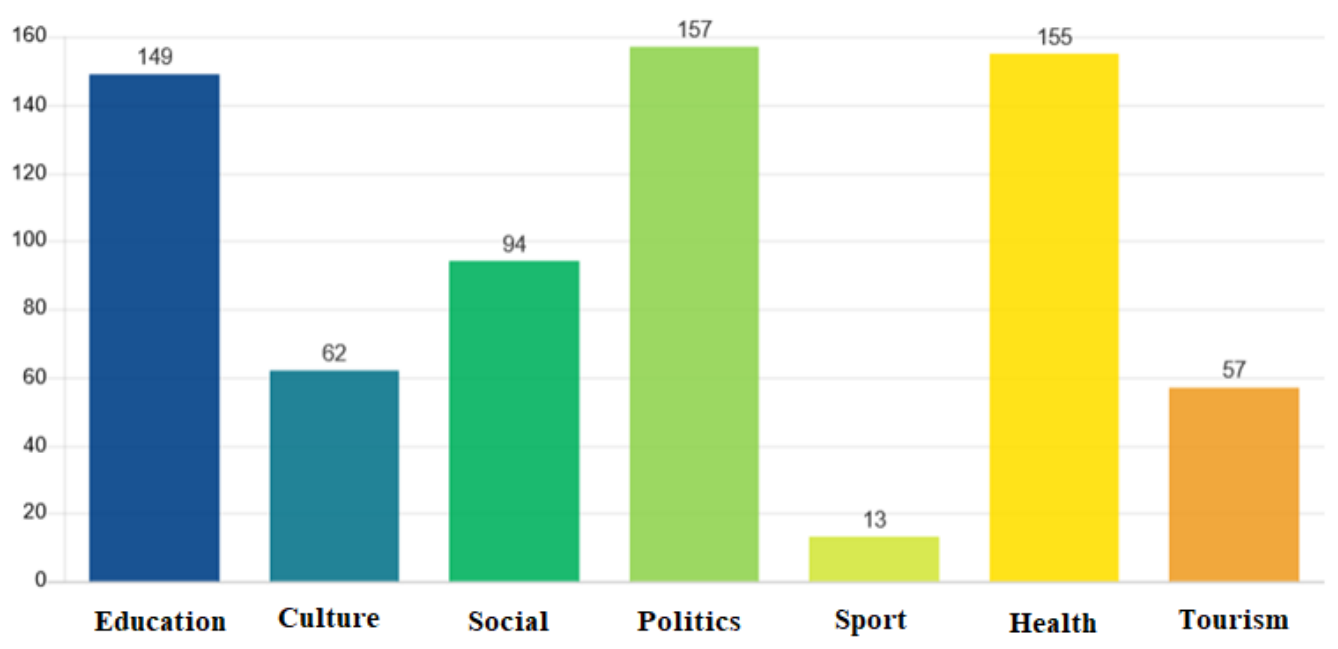

Figure 22. Which are the areas that are making you think to migrate? Source: Made by the authors based on the questionnaire available at www.isondaje.ro/sondaj/837651639/

The final argument that helps us build the model is represented by the centralizer of the answers to the last question. These can be seen in Figure 22. As we found when we stated the three main hypotheses, the political factor is decisive when it comes to the desire to migrate or stay. This is also easy to understand if we consider that the political factor influences the other factors. And the second hypothesis is verified because the following important fields are education, health and the social field, which, as in the case of politics, can be understood. Understanding the acceptance of this hypothesis derives from the fact that education and health are basic for a healthy society, and the social field has a direct impact on the safety of individuals. As in the case of the two hypotheses and the third is verified. Sport has the least impact on people's desire to migrate.

Next, after our hypotheses have been verified and, with the help of the centralized answers in figure number 22 we were able to test all the other previous questions, we will make the diagram of the migration desire. This will be based on all the existing motives in a society, synthesized on main fields: culture, social, health, education, sports, tourism and politics. 


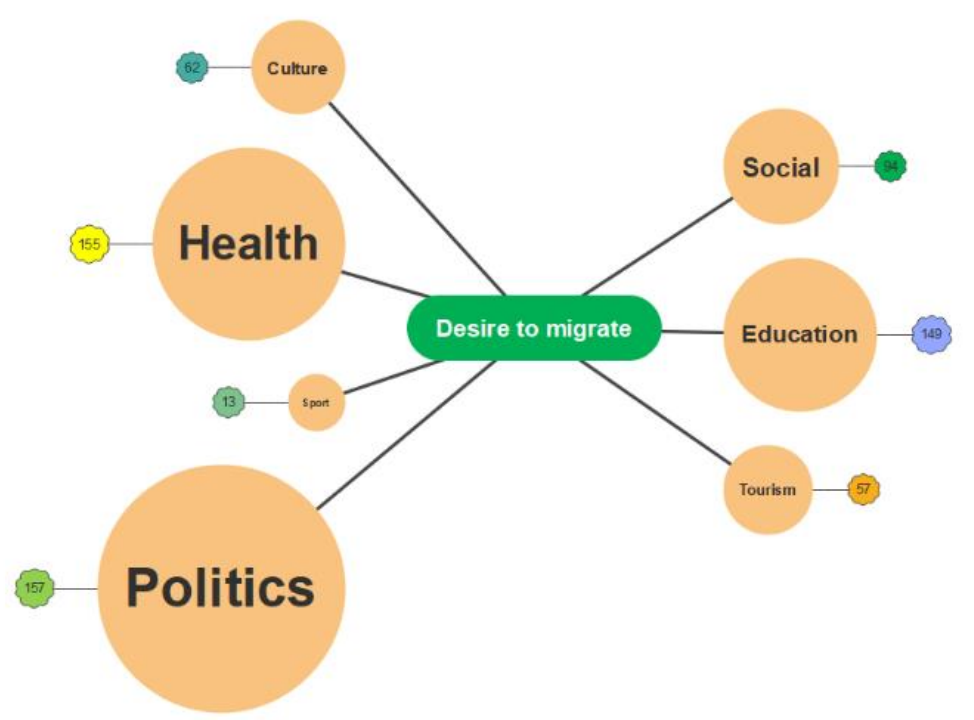

Figure 23. The deterministic model of migration (PFN)

Source: Made by the authors based on the questionnaire available at www.isondaje.ro/sondaj/837651639/

The desire to migrate, according to figure number 23 , is generated by three factors: education, politics and health. These three areas have a directly proportional impact on the desire of Romanians to migrate. If certain changes occur, they must be studied. For example, if the changes are beneficial for the population in the political sphere, the bubble of the political factor will diminish, and the diminished quantity will be unevenly distributed between the other two fields (education and health) first, and only then between the others fields (culture, tourism and sports). If the political changes have a negative impact on the population, the bubble of the political factor will grow much more than the others, taking percentages from the smallest. This stems from the fact that if a political decision has a negative impact on a person's well-being and safety, the person no longer thinks about tourism, culture, sports, but about how they will retreat or to migrate following that decision.

We also considered the situation in which we focus on an area that has less interest for those surveyed, such as sports. If the shortages and sports problems would decrease, the percentages resulting from the decrease are divided between the three biggest problems generating the desire for migration, and only then, if there are still percentages, to the others. If, instead, it will not decrease, but will increase, then this field will increase individually, naturally, without impacting (decreasing or adding) the other areas. This is because the field of sport is not as important to citizens as the others.

\section{CONCLUSIONS}

Migration is an interesting phenomenon and quite difficult to identify in a country due to its complexity. Through the model made by us we sought to show not only the reasons underlying a citizen's desire to migrate, but also how the reasons that may amplify the desire to migrate may decrease in intensity or may increase, borrowing from others important percentage reasons. We also noticed that a reason that has a very small percentage of importance in the desire to migrate, does not significantly influence, and if a reason is amplified in terms of percentage, it will collect percentages from the lowest percentage. 
We also found that people have four issues that they take into account when they want to migrate: politics, education, health and the social field. These, in a more comprehensive analysis, are part of those elements that define the level of security of citizens. The greater the deception of these four elements or the poorer management of these areas, the more people in that country will want to go to another where the four pillars are fundamental values. Moreover, depending on the fields that prevail for the citizen, we can characterize the respective nation. Thus, the model proposed by us helps us a lot both in the actual characterization of the nation, but also to see how great the desire of the population to migrate is.

\section{REFERENCES}

Alexe, A. (2019). Romania's emigrant population is the fifth largest in the world and growing. Business Review. Retrieved from: https://business-review.eu/news/romanias-emigrantpopulation-is-the-fifth-largest-in-the-world-and-growing-oecd-report-finds-203223

Arango, J., Jachimowicz, M. (2005). Regularizing Immigrants in Spain: A New Approach, Migration Policy Institute, Washington, September 1, 2005

Booth, B., Spade, J. (2003). Expanding Expatriation: The Optimal Zone Model of Mentoring Expatriates, Shippensburg, PA: Shippensburg University, Working Papers

Bortnyk, N., Didkivska, G., Tylchyk, V. (2018). The impact of international labour migration on the development of states under globalization: economic and legal aspects, Baltic Journal, 4 (2), 47-52. DOI: $10.30525 / 2256-0742 / 2018-4-2-47-52$

Botezat, A., Moraru, A. (2020). Brain drain from Romania: what do we know so far about the Romanian medical diaspora?, Eastern Journal of European Studies, 11(1), 309-334. eISSN: 2068-6633

Buhai, S. (2004). Condiţia cercetătorului: Între realitatea de acasă şi idealul din afară, Ad Astra, 3(2):1-12. Proceedings of the Conference "Migraţia tinerilor cercetători români - performanţe şi căi de intoarcere", October 14-18, 2004, Sinaia, Romania. Retrieved June 3, 2021, from http://www.ad-astra.ro/journal/6/buhai_conditia_cercetatorului.pdf

Connell, J. (2021). Doctor Retention or Migration: From Ireland to the World? Comment on "Doctor Retention: A Cross-sectional Study of How Ireland Has Been Losing the Battle", International Journal of Health Policy and Management, 10(10), 654-657. DOI: 10.34172/ijhpm.2020.196

Defoort, U. (2008). Long-term Trends in International Migration: An Analysis of the Six Main Receiving Countries, Population, 63(2), 317-351. DOI: 10.3917/popu.802.0317

De Paula, S.A., De Mello, L.F. (2021). Vulnerabilty and human mobility: a perspective from the global south about colonialism and history, Relaciones Internacionales, 47, 217-236. DOI: 10.15366/relacionesinternacionales/2021.47.011

Dumitru, S. (2010). Barometrul de opinie publică: De ce sunt românii nemulțumiți. Retrieved from: https://www.researchgate.net/publication/303044096_De_ce_sunt_romanii _nemultumiti_ Fundația_pentru_o_Societate_Deschisă: 67-79.pdf.

Duy, N.A. (2014). The Impact of International Migration \& International Remittances on Social and Economic Development: The Case of Vietnam, Proceedings of the $1^{\text {st }}$ International Conference on Finance and Economics, 390-414, June 2-4, Ho Ci Minh, Vietnam.

EURES - European Network of Employment Services (2019). Immigrants obtained a residence permit in Romania. Retrieved from: https://www.oecd-ilibrary.org/sites/890 85e47en/index.html?itemId=/content/component/89085e47-en

Fihel, A., Okólski, M. (2019). Population Decline in the Post-Communist Countries of the European Union, Population et Sociétés, 567, 1-4. Retrieved September 24, 2021, from https: //www.researchgate.net/figure/Natural-change-and-net-migration-in-the-EU-member-states1989-2017_fig1_333867652

De Haas, H., Czaika, M., Flahaux, M. et al. (2019). International Migration: Trends, Determinants, and Policy Effects, Population and Development Review, 45(4), 885-922. DOI: 10.1111/padr.12291 
Ilahi, N., Ilyina, A., Zakharova, D. (2016). Emigrația încetinește convergența Europei de Est față de Vest. Retrieved September 23, 2021, from https://www.imf.org/external/lang/ romanian/np/blog/2016/072016ar.pdf

Institutul Național de Statistică (2020). Dimensiunea populației României în anii 2000 și 2020. Retrieved from: https://insse.ro/cms/

Intotero, N. (2019). 9.7 milioane de români trăiesc în afara granițelor țării, iar mai mult de jumătate sunt in diaspora, Retrieved from: https://www.romania.europa.libera.org/a/ 30073056.html

Ion, A. (2021). Mai mult de jumătate dintre români ar pleca la muncă în străinătate. Retrieved from: https://www.capital.ro/o-cincime-dintre-romani-ar-pleca-la-munca-in-strainatate-care-estedestinatia-favorita.html

King, R., Skeldon, R. (2010). "Mind the Gap! 'Integrating Approaches to Internal and International Migration', Journal of Ethnic and Migration Studies, 36(10), 619-646. DOI: 10.1080/1369183X.2010.489380

Lavenex, S. (2005). Shifting Up and Out: The Foreign Policy of European Immigration Control, West European Politics, 29(2), 329-350. DOI: 10.1080/01402380500512684

Lucas. D. (1984). Global Trends in Migration: Theory and Research on International Population Movements, Australian Outlook, 38(1): 49. Retrieved from https://apps. webofknowledge.com/full_record.do?product=WOS\&search_mode=GeneralSearch\&qid $=6 \& \mathrm{SID}=\mathrm{D} 2 \mathrm{PDjkLlg} 8 \mathrm{Q} 7 \mathrm{OnQhicZ} \& \mathrm{page}=1 \& \mathrm{doc}=1$

Matichescu, M., Bica, A., Ogodescu, A. et al. (2015). The Romanian Migration: Development of the Phenomenon and the Part Played by the Immigration Policies of European Countries, Revista de cercetare și intervenție socială, 50, 225-238. Retrieved from https: //researchgate.net/ publication/283230679_The_romanian_migration_Development_of_the_phenomenon_and_the _part_played_by_the_immigration_policies_of_European_countries

Morawska, E., Bommes, M. (2016). International Migration Research: Constructions, Omissions and the Promises of Interdisciplinarity. London: Routledge

Naydenov, K. (2018). International Migration in Europe in the $21^{\text {st }}$ Century. Proceedings of the $4^{\text {th }}$ International Scientific Conference Geoblacanica 2018. DOI: 10.18509/GBP. 2018.22

Neagu, A. (2021). Un medic român a plecat din țară la fiecare 4 ore în anul pandemiei. Retrieved from: https://www.hotnews.ro/stiri-sanatate-24916731-exclusiv-medici-plecati-romaniapandemie.htm

Pătraşcă, L. (2005). Cariera internaţională a cercetătorilor români, Ad Astra, 4, 1-49, Retrieved from: https://www.ad-astra.ro/journal/7/patrasca.pdf

Penninx, R., Spencer, D., Van Hear, N. (2008). Migration and Integration in Europe: The State of Research. Oxford: Economic and Social Research Council (ESRC) for NORFACE (New Opportunities for Research Funding Cooperation in Europe). Retrieved from: https://www.researchgate.net/publication/237539737_Migration_and_ Integration_in_Europe_The_State_of_Research

Peticilă, M. (2019). Andronescu: 10.000 de medici au plecat din țară în ultimii doi ani. Cu educația lor, statul a cheltuit un milliard de euro. Retrieved June 2, 2021, from: https: //www.edupedu.ro/andronescu-10-000-de-medici-au-plecat-din-tara-in-ultimii-doi-ani -cueducatia-lor-statul-a-cheltuit-un-miliard-de-euro/

Population Pyramid (2000). Romania's Population Populația României în anul 2000. Retrieved from: https://www.populationpyramid.net/romania/2000/

Piramida Populației (2020). Populația României în anul 2020. Retrieved from: https:// www.populationpyramid.net/romania/2020/

Pisarevskaya, A., Levy, N., Scholten, P., Jansen, J. (2020). Mapping Migration Studies: An Empirical Analysis of the Coming of Age of a Research Field, Migration Studies, 8(3), 455- 481. DOI: 10.1093/migration/mnz03

Samofalova, E.I. (2019). Methodological Analysis of Educational Migration in Social Philosophy in the Domestic Thought, Journal of Philosophy, Sociology and Political Science, 50, 75-87. DOI: $10.17223 / 199863 \mathrm{X} / 50 / 8$

Sandu, D., Toth, G., Tudor, E. (2017). The nexus of motivation: experience in the migration process of young Romanians, Population Space and Place, 24(1), 1-16. DOI: 10.1002/ psp.2114 
Sava, J.A. (2021). Distribution of Romanian Emigrants in 2019, by Country of Detsination. Retrieved from: https://statista.com/aboutus/our-research-commitment/2480/justina-alexandra-sava

Sheridan, A. (2020). Annual report on migration and asylum 2019: Ireland, Survey and Statistical Report - Series Number 102. DOI: https://doi.org/10.26504/sustat102

Stoica, C. (2017). Migration Phenomenon at National and International Levels, Proceedings of the International Conference "Multidisciplinary Perspectives in the Quasi-Coercive Treatment of Offenders (SPECTO)", $6^{\text {th }}$ Edition, 89-93, May 11-12, Freiburg, Germany

Șerban, M., Toth, A. (2007). Piața forței de muncă în România și imigrația. Retrieved from: https://www.Downloads/docl_18858_873206772\%20(1).pdf 